\title{
Epidemiological and Clinico-Pathological Characteristics of Bladder Cancer at Clinical Oncology Department, Zagazig University: Retrospective Analysis Osama Abdel Fattah*1,Yousra Dorgham ${ }^{1}$, Mohammed Abdelgawad ${ }^{1}$, Ibrahim Nasr ${ }^{2}$ \\ Departments of ${ }^{1}$ Clinical Oncology and ${ }^{2}$ Nuclear Medicine, \\ Faculty of Medicine, Zagazig University, Sharkia, Egypt. \\ *Correspondence to: Osama Abdel Fattah ElSayed Attiya, Mobile: (+20)1004600539, E-mail: osama866@ @otmail.com
}

\begin{abstract}
Background: Bladder cancer is the ninth most common cancer worldwide, with an estimated 430000 new cases in 2012. Transitional Cell Carcinoma (TCC) represents 90\% to 95\% of malignant bladder tumors.

Objective: This retrospective observational study was done to analyze age, gender, histological characteristics in patients with bladder cancer.

Patients and Methods: The whole number of UBC cases diagnosed, treated at the Clinical Oncology Department, Zagazig University Hospital, Sharkia, Egypt from 2013 to 2018 was found in 328 cases; 270 males $(82.3 \%)$ and 58 females $(17.7 \%)$. Major clinic-pathological parameters were systematically collected from records and investigated in this study.

Results: In the present study, the age of the patients ranged between 26 to 92 years, more than half of cases $(69.2 \%)$ were $>60$ years. $73.2 \%$ of cases live in Rural areas and only $26.8 \%$ were Urban. In our study, $86.6 \%$ don't have Bilharziasis and only presented at $13.4 \%$. More than half of them were smokers $(63.7 \%)$. Our study showed that $78.3 \%$ of cases were of the urothelial type of carcinoma. Our study showed that $60 \%$ of tumors were less than $3 \mathrm{~cm}, 34.8 \%$ were from $3-5 \mathrm{~cm}, 5.2 \%$ were more than $5 \mathrm{~cm}$. As regard the tumor grade, 52.7 were of grade III, $27.7 \%$ were of grade II, $19.5 \%$ were grade I, $98.2 \%$ had no CIS, $95.1 \%$ had no LVI, $84.5 \%$ had lamina propria invasion, $66.4 \%$ had muscle invasion, 80.75 had no extravesical extension.

Conclusion: Bladder cancer occurs most commonly in the elderly with male predominance. Hematuria was the most common complaint of patients with bladder cancer.

Keywords: Epidemiological, Clinico-Pathological Characteristics, Bladder Cancer.
\end{abstract}

\section{INTRODUCTION}

Bladder cancer is the ninth most common cancer throughout the world and is considerably more common in developed than developing countries. Bladder cancer is the fourth most common cancer in men and the fifth most commonly diagnosed cancer in the United States. In 2006, approximately 44,690 men and 16,730 women will be newly diagnosed with bladder cancer in the United States ${ }^{(\mathbf{1})}$.

In Egypt, it is the most prevalent cancer in men $(16 \%)$ and the second most common cancer in women (12\%), producing more than7900 deaths annually, which is strikingly higher than most other parts of the world $^{(2)}$.

$\mathrm{BC}$ is pathologically classified into two groups: non-muscle-invasive $\mathrm{BC}$ (NMIBC) and muscleinvasive BC (MIBC). Approximately $50 \%$ to $80 \%$ of bladder cancer patients are characterized with NMIBC which can be treated by removing the tumor by transurethral approaches. Unfortunately, NMIBC may recur, and approximately $25 \%$ of cases progress to MIBC which is the main cause of death ${ }^{(3)}$.

Cancer acquires a set of functional biological capabilities during its multistep development including sustaining proliferative signaling, evading growth suppressors, resisting cell death, enabling replicative immortality, inducing angiogenesis, and activating invasion and metastasis. Cancers arising in the urothelial tract display a wide spectrum of variant morphologies. Tumors composed of purely variant histologies tend to have worse survival. The neoplastic changes in the urothelium of the bladder are a multistep phenomenon involving the activation of oncogenes, and inactivation or loss of tumor suppressor genes ${ }^{(3)}$.

This retrospective observational study was done to analyze age, gender, histological characteristics in patients with bladder cancer.

\section{PATIENTS AND METHODS}

This was a retrospective study on urinary bladder cancer patients treated at Clinical Oncology Department, Zagazig University Hospital between 2013 to 2018. Medical records of 328 patients, who were referred to our Clinical Oncology Department after proved diagnosis with Urinary Bladder cancer, underwent TURBT, laboratory, and radiological examination after complaints of hematuria or dysuria.

\section{Data collection:}

Via histopathological reports, staging and metastatic workup including TURBT, CT abdomen and pelvis, pelvi-abdominal $\mathrm{U} / \mathrm{S}$, and isotope bone scan. 


\section{Study parameters and their definition:}

- Major clinic-pathological parameters were systematically collected from records and investigated in this study (age, sex of patients, CTs results, site of the tumor, preoperative diagnostic investigations, presence or absence of distant metastasis before surgery, and histopathology report which included: location, size, and grade of tumor, depth of invasion, LVI, PNI, LN involvement, presence of synchronous cancer and margin status).

- Age of patients divided into three groups $(<40,40-$ 60 , and more than $>60$ years).

- The sex of patients was divided into two groups (males and females).

- The intent of management whether curative or palliative.

\section{Ethical consent :}

Approval of the study was obtained from Zagazig University academic and ethical committee.

Every patient signed informed written consent for the acceptance of the operation. This work has been carried out following The Code of Ethics of the World Medical Association (Declaration of Helsinki) for studies involving humans.

\section{Statistical analysis}

The collected data were coded, processed, and analyzed using the SPSS (Statistical Package for Social Sciences) version 22 for Windows ${ }^{\circledR}$ (IBM SPSS Inc, Chicago, IL, USA). Data were tested for normal distribution using the Shapiro Walk test. Qualitative data were represented as frequencies and relative percentages. Chi-square test $(\chi 2)$ to calculate the difference between two or more groups of qualitative variables.

Quantitative data were expressed as mean \pm SD (Standard deviation). Independent samples t-test was used to compare between two independent groups of normally distributed variables (parametric data). Pvalue $<0.05$ was considered significant.

\section{RESULTS}

This study was conducted on 328 cases in which demographic data are presented in table (1). There were 270 males $(82.3 \%)$ and 58 females $(17.7 \%)$. Their age ranged from 26 to 92 years, more than half of cases $(69.2 \%)$ were $>60$ years. $73.2 \%$ of cases live in rural and only $26.8 \%$ in urban areas. $86.6 \%$ don't have Bilharziasis and only presented at $13.4 \%$. More than half of them were smokers $(63.7 \%)$.

Table (1): Demographic data of the studied urinary bladder cancer patients $(n=328)$

\begin{tabular}{|l|c|c||}
\hline & No. & \% \\
\hline Age (years) & 3 & \\
<40 years & 9.9 \\
40-60 years & 98 & 29.9 \\
>60 years & 227 & 69.2 \\
\hline Sex & 270 & 82.3 \\
Male & 58 & 17.7 \\
Female & & \\
\hline Residence & 240 & 73.2 \\
Rural & 88 & 26.8 \\
Urban & & \\
Bilharziasis & 284 & 86.6 \\
Absent & 44 & 13.4 \\
Present & & \\
Smoking & 119 & 36.3 \\
Non-smoker & 209 & 63.7 \\
Smoker & & \\
\hline Occupation & 235 & 71.7 \\
Farmer & 30 & 9.1 \\
Industrial worker & 63 & 19.2 \\
\hline Other
\end{tabular}

$\mathrm{n}$ is the number of cases

Table (2) shows that $78.3 \%$ of cases were of the urothelial type of carcinoma, followed by mixed type in $12.8 \%$, adenocarcinoma was in $2.1 \%$ and squamous type in $6.7 \%$, then as regard the tumor grade, 52.7 were of grade III, $27.7 \%$ were of grade II, $19.5 \%$ were grade I, $98.2 \%$ had no CIS, $95.1 \%$ had no LVI, $84.5 \%$ had lamina propria invasion, $66.4 \%$ had muscle invasion, 80.8 had no extravesical extension, then as regard staging; $47.9 \%$ were of $\mathrm{T} 2,23.8 \%$ were $\mathrm{T} 1$, $90.5 \%$ were $\mathrm{N} 0$, and $74.7 \%$ were $\mathrm{M} 0$. 
Table (2): Distribution of the studied cases according to histopathological and radiological data of bladder cancer patients $(\mathrm{n}=328)$

\begin{tabular}{|c|c|c|}
\hline Pathology & No. & $\%$ \\
\hline $\begin{array}{l}\text { Histopathology } \\
\text { Urothelial } \\
\text { Adenocarcinoma } \\
\text { Squamous } \\
\text { Mixed }\end{array}$ & $\begin{array}{c}257 \\
7 \\
22 \\
42\end{array}$ & $\begin{array}{c}78.4 \\
2.1 \\
6.7 \\
12.8\end{array}$ \\
\hline $\begin{array}{l}\text { Grading } \\
\text { Grade I } \\
\text { Grade II } \\
\text { Grade III } \\
\end{array}$ & $\begin{array}{c}64 \\
91 \\
173\end{array}$ & $\begin{array}{l}19.5 \\
27.7 \\
52.8\end{array}$ \\
\hline $\begin{array}{l}\text { CIS } \\
\text { Absent } \\
\text { Present }\end{array}$ & $\begin{array}{c}322 \\
6 \\
\end{array}$ & $\begin{array}{c}98.2 \\
1.8 \\
\end{array}$ \\
\hline $\begin{array}{l}\text { LVI } \\
\text { Absent } \\
\text { Present }\end{array}$ & $\begin{array}{c}312 \\
16\end{array}$ & $\begin{array}{c}95.1 \\
4.9\end{array}$ \\
\hline $\begin{array}{l}\text { Lamina propria invasion } \\
\text { Absent } \\
\text { Present }\end{array}$ & $\begin{array}{c}51 \\
277\end{array}$ & $\begin{array}{l}15.5 \\
84.5\end{array}$ \\
\hline $\begin{array}{l}\text { Muscle invasion } \\
\text { Absent } \\
\text { Present }\end{array}$ & $\begin{array}{l}110 \\
218\end{array}$ & $\begin{array}{l}33.5 \\
66.5\end{array}$ \\
\hline $\begin{array}{l}\text { Extravesical extension } \\
\text { Absent } \\
\text { Present }\end{array}$ & $\begin{array}{c}265 \\
63\end{array}$ & $\begin{array}{l}80.8 \\
19.2\end{array}$ \\
\hline $\begin{array}{l}\text { PNI } \\
\text { Absent } \\
\text { Present }\end{array}$ & $\begin{array}{c}317 \\
11\end{array}$ & $\begin{array}{c}96.6 \\
3.4\end{array}$ \\
\hline $\begin{array}{c}\text { T stage } \\
\text { T0 } \\
\text { T1 } \\
\text { T2 } \\
\text { T3 } \\
\text { T4 }\end{array}$ & $\begin{array}{c}25 \\
78 \\
157 \\
50 \\
18\end{array}$ & $\begin{array}{c}7.6 \\
23.8 \\
47.9 \\
15.2 \\
5.5\end{array}$ \\
\hline $\begin{array}{c}\text { N stage } \\
\text { N0 } \\
\text { N1 } \\
\text { N2 } \\
\text { N3 }\end{array}$ & $\begin{array}{c}297 \\
19 \\
11 \\
1\end{array}$ & $\begin{array}{c}90.5 \\
5.8 \\
3.4 \\
0.3\end{array}$ \\
\hline $\begin{array}{c}\text { M stage } \\
\text { M0 } \\
\text { M1 } \\
\text { Mx }\end{array}$ & $\begin{array}{c}245 \\
79 \\
4\end{array}$ & $\begin{array}{c}74.7 \\
24.1 \\
1.2\end{array}$ \\
\hline
\end{tabular}

Table (3) shows that $96.4 \%$ of cases were of TURBT type of biopsy, $0.9 \%$ only were of urine cytology type, $2.4 \%$ were FNAB. then as regards type of surgery, $80.8 \%$ were of TURBT type, $8.5 \%$ undergone cystectomy, $5.2 \%$ were TURBT then Cystectomy. while as regard site of the tumor, $34.8 \%$ were in the right lateral wall, followed by $25.3 \%$ were in the left lateral wall, $11.6 \%$ were in the dome, and $5.2 \%$ were in trigone, furthermore as regard centricity; $87.5 \%$ were solitary and $12.5 \%$ were multiple centered, then as regard growth pattern; $90.9 \%$ were of papillary pattern, and the table shows that $60 \%$ of tumors were less than $3 \mathrm{~cm}, 34.8 \%$ were from $3-5 \mathrm{~cm}$, $5.2 \%$ were $>5 \mathrm{~cm}$.

Table (3): Distribution of the studied cases according to pathological characteristics $(\mathrm{n}=328)$

\begin{tabular}{|c|c|c|}
\hline $\begin{array}{c}\begin{array}{c}\text { Pathological } \\
\text { characteristics }\end{array} \\
\end{array}$ & No. & $\%$ \\
\hline $\begin{array}{l}\text { Type of biopsy } \\
\text { TURBT } \\
\text { Urine cytology } \\
\text { FNAC }\end{array}$ & $\begin{array}{c}317 \\
3 \\
8\end{array}$ & $\begin{array}{l}96.4 \\
0.9 \\
2.4\end{array}$ \\
\hline $\begin{array}{c}\text { Type of surgery } \\
\text { TURBT } \\
\text { Cystectomy } \\
\text { TURBT then } \\
\text { Cystectomy } \\
\end{array}$ & $\begin{array}{c}273 \\
28 \\
27\end{array}$ & $\begin{array}{l}83.3 \\
8.5\end{array}$ \\
\hline $\begin{array}{l}\text { Site of tumor } \\
\text { Right lateral wall } \\
\text { Left lateral wall } \\
\text { Trigone } \\
\text { Dome } \\
\text { Bladder neck } \\
\text { Diffuse } \\
\end{array}$ & $\begin{array}{l}114 \\
83 \\
17 \\
38 \\
19 \\
57\end{array}$ & $\begin{array}{c}34.8 \\
25.3 \\
5.2 \\
11.6 \\
5.8 \\
17.3 \\
\end{array}$ \\
\hline $\begin{array}{l}\text { Multicentricity } \\
\text { Solitary } \\
\text { Multiple } \\
\end{array}$ & $\begin{array}{c}287 \\
41\end{array}$ & $\begin{array}{l}87.5 \\
12.5\end{array}$ \\
\hline $\begin{array}{l}\text { Growth pattern } \\
\quad \text { Solid } \\
\text { Papillary }\end{array}$ & $\begin{array}{c}30 \\
298\end{array}$ & $\begin{array}{c}9.1 \\
90.9\end{array}$ \\
\hline $\begin{array}{l}\text { Tumor size }(\mathbf{c m}) \\
\quad<3 \\
3-5 \\
>5 \\
\end{array}$ & $\begin{array}{c}197 \\
114 \\
17\end{array}$ & $\begin{array}{c}60.1 \\
34.8 \\
5.2 \\
\end{array}$ \\
\hline
\end{tabular}

\section{DISCUSSION}

Bladder cancer (BC) is one of several types of cancer arising from the epithelial lining of the urinary bladder. The most common type of bladder cancer recapitulates the normal histology of the urothelium and is known as transitional cell carcinoma or more properly urothelial cell carcinoma. Five-year survival rates in the United States are around $77 \%$. The incidence in women is approximately 3-4 times lower than in men but it seems to be rising ${ }^{(4)}$.

Although bladder cancer ranks lower in the total number of cancer-related deaths than it does in incidence, it has the eminence of being the malignancy with the fastest rate of recurrence which results in a very high prevalence. The incidence increases with age, smoking, living in urban areas, and working in dye, rubber, or leather industries ${ }^{(5)}$.

In Egypt, $\mathrm{BC}$ has been the most common cancer during the past 50 years. In 2002, Egypt's worldstandardized BC incidence was 37/100,000, representing approximately 30,000 new cases each year. Interestingly, the most common histopathological type of BC in Egypt has been SCC, constituting from $59 \%$ to $81 \%$ of reported BC between 1960 and 1980 . 
Contrary to the leading etiology of smoking and occupational exposures in Western countries, chronic bladder inflammation and infection with Schistosoma haematobium, the trematode causing urinary schistosomiasis, has been the most important risk factor for bladder cancer in $\operatorname{Egypt}^{\left({ }^{(6)}\right.}$.

There are medical records rooms in different institutions dealing with the registry of bladder cases with variable degrees of sophistication. All these attempts to register cancer are hospital-based. Until now, the Sharkia Governorate had no hospital-based bladder registration. Until now, Sharkia Governorate had no hospital-based bladder registration.

Therefore, the present study aimed to analyze age, gender, histological characteristics in patients with bladder cancer. The whole number of UBC cases diagnosed, treated at the Clinical Oncology Department, Zagazig University Hospital from 2013 to 2018 was found in 328 cases; 270 males $(82.3 \%)$ and 58 females (17.7\%). Their age ranged from 26 to 92 years, more than half of cases $(69.2 \%)$ were $>60$ years.

The largest proportion of patients (39.8\%) with bladder cancer in a study were older than 70 years ${ }^{(7)}$. Amin $^{(8)}$ knew the histopathological aspect of urinary bladder cancer (UBC), risk factors, response to treatment in Assuit University Hospital, oncology department. Ninety-seven cases of histological proven primary urinary bladder tumor data were analyzed. The patients range in age from (30-91) years and the mean age was 58.34 years. There were 85 males and 12 females, male: female ratio was $7: 1$ (male is significantly affected more than female. Rambau et al. (9) showed $58.4 \%$ of the patients with bladder cancer were older than 50 years of age.

Also, Ramezani et al. (10) evaluated epidemiological and clinicopathological features of bladder cancer. Overall, 220 patients were registered. $179(81.4 \%)$ patients were men. Mean \pm SD age at diagnosis was $62.5 \pm 15.1$ years (range: $14-90$ years). Most patients (60.9\%) were $>60$ years old.

Therefore, the results confirmed that bladder cancer occurs most commonly in the elderly. Bladder cancer is more common in men. Therefore, the prevalence of bladder cancer in men in Africa is reported to be higher than in Europe and Asia.

In our study, $73.2 \%$ of cases live in rural and only $26.8 \%$ in urban areas. Also, Ramezani et al. ${ }^{(10)} 10$ found that $165(75 \%)$ patients were from rural and 55 $(25 \%)$ patients were from urban areas. But, in a study, $95.5 \%$ of patients with bladder cancer came from urban areas ${ }^{(11)}$.

In our study, $86.6 \%$ don't have Bilharziasis and only presented at $13.4 \%$. Amin ${ }^{(8)}$ found a history of bilharziasis in $27.8 \%$ of TCC, SCC, and TCC with squamous differentiae.

In this study, more than half of them were smokers $(63.7 \%)$. Salehi et al. ${ }^{(7)}$ showed that tobacco and opium use was found in $109(65.3 \%)$ and 44 $(34.1 \%)$ of the patients, respectively. Amin ${ }^{(8)}$ found a history of smoking in $47.3 \%$ of TCC, SCC, TCC with squamous differentiae.

Kobeissi et al. ${ }^{(12)}$ have shown significant associations between bladder cancer and environmental factors such as tobacco smoking and occupational exposures. It has been shown that smoking increases the production of numerous proinflammatory cytokines such as TNF- $\alpha$, IL-1, IL-6, IL8 GM-CSF and decreases the levels of antiinflammatory cytokines such as IL-10.

Ebadi et al. ${ }^{(13)}$ and Lu et al. ${ }^{(14)}$ found that $45.21 \%$ and $61.29 \%$ of BC patients respectively were current smokers, and they stated that cigarette smoking is significantly associated with increased risk of bladder cancer compared to healthy individuals. Ramezani et al. ${ }^{\left({ }^{(10)}\right.}$ found that 71 (43\%) out of 165 patients had a positive history of smoking.

Our study showed that $78.3 \%$ of cases were of the urothelial type of carcinoma, followed by mixed type in $12.8 \%$, adenocarcinoma was in $2.1 \%$ and squamous type in $6.7 \%$, then as regard the tumor grade, 52.7 were of grade III, $27.7 \%$ were of grade II, $19.5 \%$ were grade I, $98.2 \%$ had no CIS, $95.1 \%$ had no LVI, $84.5 \%$ had lamina propria invasion, $60.4 \%$ had muscle invasion, 70.75 had no extravesical extension.

Mahesh and Yelikar ${ }^{(15)}$ found that small cell carcinoma and adenocarcinoma are uncommon tumors of the bladder and account for about 0.5 and $2 \%$ of all bladder cancers, respectively. Vaidya et $\boldsymbol{a l} .{ }^{(16)}$ saw one $(8.75 \%)$ case of adenocarcinoma.

Our study showed that $96.4 \%$ of cases were of TURBT type of biopsy, $0.9 \%$ only were of urine cytology type, $2.4 \%$ were FNAB. Kim et al. ${ }^{(17)}$ investigated the clinicopathological characteristics of urinary bladder tumors in patients $<20$ years and examined voided urine cytology in all patients, with the results found to be negative in all cases.

As regards the site of the tumor, $34.8 \%$ were in the right lateral wall, followed by $25.3 \%$ were in the left lateral wall, $11.6 \%$ were in the dome, and $5.2 \%$ were in the trigone. Amin ${ }^{(8)}$ found the location of the tumor within the bladder mainly as overlapping lesion $46.4 \%$, followed by lateral wall $27.8 \%$, dome of the bladder in $14.4 \%$.

As regard centricity; $87.5 \%$ were solitary and $12.5 \%$ were multiple centered, then as regard growth pattern; $90.9 \%$ were of the papillary pattern. Sathya and Chinnaswamy ${ }^{(18)}$ found that TCC cases were papillary, $9(12.5 \%)$ were solid, the cells were identical to normal urothelium, absences of mitosis, and the presence of single layer cuboidal cells, whereas 61 $(987.5 \%)$ were both papillary and solid with ordered or disordered cells, crowding, frequent loss of polarity with moderate-marked pleiomorphism and variable thickness. Kim et $\boldsymbol{a l} .{ }^{(\mathbf{1 7 )}}$ showed that all tumors were solitary and polypoid lesions with stalks.

Our study showed that $60 \%$ of tumors were less than $3 \mathrm{~cm}, 34.8 \%$ were from $3-5 \mathrm{~cm}, 5.2 \%$ were more than $5 \mathrm{~cm}$. Sathya and Chinnaswamy ${ }^{(18)}$ found that nine out of 70 patients $(12.8 \%)$ showed tumor size of 
4-5 cm, 18 patients out of $70(25.7 \%)$ showed a tumor size of $3-3.5 \mathrm{~cm}$, and 35 out of 70 patients $(50 \%)$ showed tumor size of $1-2.5 \mathrm{~cm}$.

Our study showed that that $78.3 \%$ of cases were of the urothelial type of carcinoma, followed by mixed type in $12.8 \%$, adenocarcinoma was in $2.1 \%$, and squamous type in $6.7 \%$. The frequency of different bladder cancers in a study was reported with TCC as the most common (95.7\%), followed by adenocarcinoma $(1.1 \%)$ and SCC $(0.5 \%)^{(7)}$.

Amin $^{(8)}$ found that transitional cell carcinoma TCC was the most predominant histological type $(60.8 \%)$. The frequency of squamous cell carcinoma SCC were $(26.8 \%)$ and adenocarcinoma was $6.2 \%$. Ramezani et al. (10) found that squamous cell carcinoma (SCC) and adenocarcinoma with equal frequency comprised the other pathological subtypes.

As regard the tumor grade, 52.7 were of grade III, $27.7 \%$ were of grade II, $19.5 \%$ were grade I, $98.2 \%$ had no CIS, $95.1 \%$ had no LVI, $84.5 \%$ had lamina propria invasion, $66.4 \%$ had muscle invasion, 80.75 had no extravesical extension. Sathya and Chinnaswamy $^{(18)}$ found that TCCs showed histological signs of 18 out of 70 patients with muscle invasion (infiltrative) at diagnosis, 53 out of 70 patients without muscle invasion. Sixty-one out of 70 (87\%) patients have shown the lamina propria invasion, 18 out of $70(25.7 \%)$ have shown lymph vascular space invasion. This is similar to the observations reported by Laishram et al. ${ }^{(\mathbf{1 9})}$.

As regard staging, $47.9 \%$ were $\mathrm{T} 2,23.8 \%$ were T1, $90.5 \%$ were N0, and $74.7 \%$ were M0. Amin ${ }^{(8)}$ found TCC stage II, III in 43/59 patients, where 7/59 patients were presented as non-invasive bladder cancer (stage 1), where in SCC and adenocarcinoma, all are infiltrative. Metastatic bladder cancer was found in $15 / 97$ patients, the main site of metastases is bone 12.4\%. Ramezani et al. ${ }^{(10)}$ found that of the 205 patients with TCC, one $(0.5 \%)$ patient, and 85 $(41.5 \%), 76(37 \%)$ and $43(21 \%)$ patients had grade I, II, III and IV tumors, respectively. Grade II had the most frequency and Grade I had the lowest in both sex.

From the present study, we can conclude that bladder cancer occurs most commonly in the elderly with male predominance. Hematuria was the most common complaint of patients with bladder cancer; as a result, physicians should be alert to refer patients with this symptom for further evaluation particularly in the elderly.

\section{Financial support and sponsorship: Nil.}

Conflict of interest: Nil.

\section{REFERENCES}

1. Schulz G, Grimm T, Buchner A et al. (2020): Bladder Cancer Stage Development, 2004-2014 in Europe Compared With the United States: Analysis of European Population-based Cancer Registries, the United States
SEER Database, and a Large Tertiary Institutional Cohort. Clinical Genitourinary Cancer, 18(3): 162-170.

2. Andreassen B, Grimsrud T, Haug E (2018): Bladder cancer survival: women better off in the long run. European Journal of Cancer, 95: 52-58.

3. Al-Ahmadie H, Bellmunt J, Guo G et al. (2017): Comprehensive molecular characterization of muscleinvasive bladder cancer. Cell, 171(3): 540-556.

4. Unruhe B, Schroder E, Wunsch D et al. (2016): An Old Flame Never Dies: Survivin in Cancer and Cellular Senescence. Gerontology, 62: 173-81.

5. Srivastava A, Singh P, Srivastava $K$ et al. (2013): Diagnostic role of survivin in urinary bladder cancer. Asian Pac. J. Cancer Prev., 14: 81-85.

6. Abou-El-Naga I (2018): Towards elimination of schistosomiasis after 5000 years of endemicity in Egypt. Acta Tropica, 181: 112-121.

7. Salehi A, Khezri A, Malekmakan L et al. (2011): Epidemiologic status of bladder cancer in Shiraz, southern Iran. Asian Pac J Cancer Prev., 12(5): 1323-7.

8. Amin A (2013): Epidemiological study of bladder cancer and risk factors in Upper Egypt. AAMJ., 11(2): 305-316.

9. Rambau P, Chalya P, Jackson K (2013): Schistosomiasis and urinary bladder cancer in NorthWestern Tanzania: a retrospective review of 185 patients. Infect Agent Cancer, 8(1):19-23.

10. Ramezani M, Naderi N, Almasi A et al. (2016): Epidemiological and clinicopathological features of bladder cancer: A report from Kermanshah Province, Iran. IJBC., 8(2): 43-46.

11. Rabbani F, Cordon-Cardo C (2000): Mutation of cell cycle regulators and their impact on superficial bladder cancer. Urol Clin North Am., 27(1): 83-102.

12. Kobeissi L, Yassine I, Jabbour M et al. (2013): Urinary bladder cancer risk factors: a Lebanese casecontrol study. Asian Pac J Cancer Prev., 14: 3205-3211.

13. Ebadi N, Jahed M, Mivehchi M et al. (2014): Interleukin-12 and Interleukin-6 Gene Polymorphisms and Risk of Bladder Cancer in the Iranian Population. Asian Pac J Cancer Prev., 15(18): 7869-7873.

14. Lu L, Wu L, Chen $H$ et al. (2016): Association of proinflammatory cytokines gene polymorphisms with risk of bladder cancer in the Han Chinese population. Int J Clin Exp Med., 9(8): 16558-16567.

15. Mahesh K, Yelikar B (2012): Spectrum of lesions in cystoscopic bladder biopsies: A histopathological study. Al Ameen J Med Sci., 5: 132-136.

16. Vaidya S, Lakhey M, Sabira K et al. (2013): Urothelial tumors of the urinary bladder: A histopathological study of cystoscopic biopsies. J Nepal Med Assoc., 52: 475478.

17. Kim S, Park S, Song S et al. (2018): CLinicopathological characteristics of urinary bladder tumors in Korean patients 20 years or younger. J Korean Med Sci., 33(40): 242-46.

18. Sathya M, Chinnaswamy $P$ (2014): Urinary bladder cancer: A clinicopathological and histological study. J Med Sci., 14(4): 206-209.

19. Laishram $R$, Kipgen $P$, Laishram $S$ et al. (2012): Urothelial tumors of the urinary bladder in Manipur: A histopathological perspective. Asian Pac J Cancer Prev., 13: 2477-2479. 